Roomet Jakapi

Tartu Ülikool, Estonia

e-mail: roomet.jakapi@ut.ee

\title{
Conflicting Models of Faith: Browne vs Toland
}

DOI: http://dx.doi.org/10.12775/RF.2016.039

\section{Introduction}

An Irish freethinker, John Toland (1670-1722), published his scandalous treatise Christianity Not Mysterious (hereafter CNM) in 1696. His account of the Christian revelation as thoroughly clear and comprehensible, the conception of a genuine, rational Christianity that has no supernatural dimension, his anticlerical sentiment, and several other facets of his thought provoked much criticism. Several responses were published over the following years. ${ }^{1}$ Best known among the direct responses to the book by Toland is A Letter in Answer to a Book entitled Christianity Not Mysterious (hereafter Answer) written by another Irishman, an Anglican priest and philosopher, Peter Browne (1665-1735). The Answer, published in 1697, became the first in a series where Browne advanced his theory of divine analogy. ${ }^{2}$

The debate on the nature of Christian revelation and mysteries is an essential part of what has been called the Deist controversy ${ }^{3}$ in the history of Early Modern thought in England and Ireland. Deism, including

1 See A. R. Winnett, Peter Browne: Provost, Bishop, Metaphysician, p. 217 for references.

2 The two other books were P. Browne, The procedure, limits, and extent of human understanding, and Things divine and supernatural conceived by analogy with things natural and human.

3 See R. E. Sullivan, John Toland and the Deist controversy: A study in adaptations. 
Toland's thought, has been studied by scholars for a long time. ${ }^{4}$ Recently, a wave of new interpretations has emerged. The historical concept of Deism and the variety of views held and opposed by the deists have now been analysed and presented in a great detail. ${ }^{5}$ Toland's rhetoric ${ }^{6}$, his debt to Spinoza and LeClerc, ${ }^{7}$ his selective adoption and rejection of Locke's ideas ${ }^{8}$ have also been carefully explained in recent literature.

Peter Browne's philosophy has not received so much attention from scholars. ${ }^{9}$ I believe that Browne's reading of Toland deserves another look both from a historical perspective and from the perspective of current debates on the nature of faith in the philosophy of religion. This paper aims to interpret and analyse the positions of Toland and Browne as conflicting models of faith. ${ }^{10}$ While the source materials of this study are historical, the approach will not be strictly historical and contextual. Rather, I will try to apply the concept of "model of faith", as understood in contemporary philosophy, to the historical positions in question. The focus will be on the cognitive aspects of religious faith, leaving out af-

4 For classic studies of English Deism, see G. V. Lechler, Geschichte des englischen Deismus; L. Stephen, History of English Thought in the Eighteenth Century, Vol. 1; S. G. Hefelbower, The Relation of John Locke to English Deism. For more recent books on Toland, see R. E. Sullivan, John Toland and the Deist controversy: A study in adaptations, and S. H. Daniel, John Toland: His methods, manners, and mind. For a systematic as well as historical account of Deism, see P. Byrne, Natural Religion and the Nature of Religion: The Legacy of Deism. For a comprehensive intellectual history of the time, including a survey of English Deism, see J. I. Israel, Radical Enlightenment: Philosophy and the Making of Modernity 1650-1750.

5 See J. Champion, Republican Learning: John Toland and the Crisis of Christian Culture, 1696-1722; D. Lucci, Scripture and Deism. The Biblical Criticism of the EighteenthCentury British Deists; W. Hudson, The English Deists; J. R. Wigelsworth, Deism in Enlightenment England. Theology, Politics, and Newtonian Public Science; L. Jaffro, "John Toland and the Moral Teaching of the Gospel"; W. Hudson, D. Lucci and J. R. Wigelsworth (eds.), Atheism and Deism Revalued. Heterodox Religious Identities in Britain, 1650-1800.

6 See D. C. Fouke, Philosophy and Theology In A Burlesque Mode: John Toland and "The Way Of Paradox".

7 See I. Leask, “The Undivulged Event in Toland's Christianity Not Mysterious", and L. Simonutti, "Deism, Biblical Hermeneutics and Philology".

8 See I. Leask, "Personation and Immanent Undermining: On Toland's Appearing Lockean", and J. S. Marko, Measuring the Distance between Locke and Toland: Reason, Revelation, and Rejection during the Locke-Stillingfleet Debate.

9 There is a classic monograph on Browne's life and works: A. R. Winnett, Peter Browne: Provost, Bishop, Metaphysician. For discussions of Browne's account of divine analogy, see P. J. Olscamp, The Moral Philosophy of George Berkeley, pp. 204-222; J. O'Higgins, "Browne and King, Collins and Berkeley: Agnosticism or Anthropomorphism?"; T. Duddy, A History of Irish Thought, pp. 98-105; T. Curtain, "Divine Analogy in Eighteenth-Century Irish Philosophy"; D. Linford, "Early-Modern Irreligion and Theological Analogy: A Response to Gavin Hyman's A Short History of Atheism".

10 See J. Bishop, "Faith". 
fective and practical aspects. ${ }^{11}$ That is to say, I will characterise Toland's and Browne's models of faith in terms of knowledge, belief, and their objects. The descriptions of these models will also include such relevant features as the relationship between divine revelation and human reason, the cognitive content of religious mysteries, human representations of divine things, and rational grounds of faith.

I shall argue that the views of Toland and Browne on divine revelation, religious mysteries, and the meaning of religious language are, in certain respects, closer to one another than often assumed. At the same time, I aim to show that a systematic disagreement between their positions is evident in their respective accounts of the nature and ultimate objects of Christian faith. I claim that Toland takes the Christian faith to be a special kind of natural knowledge, whereas Browne understands it as a set of voluntary beliefs concerning supernatural things that are partly revealed.

In the first main section of the paper, I present Toland's conception of Christian revelation and faith. The second section is concerned with Browne's reading of CNM, and his conceptions of divine analogy and faith. Finally, in the third section, I draw specific conclusions from the comparison of the models of Christian faith proposed by these two thinkers.

\section{Toland on Christian Faith}

The aims, methods, and views of Toland at different stages of his intellectual career are a matter of careful and nuanced debates among scholars. ${ }^{12}$ In hermeneutic perspective, he is a complicated and puzzling object of study, an author whose intentions and implications behind the words are neither uniform nor easy to determine. In what follows, I shall not offer a contextualising reading of $\mathrm{CNM}$ but rather try to reconstruct the conception or model of Christian faith that he appears to propose in that treatise.

According to Toland, the genuine Christian religion cannot contain any articles of faith that contradict or transcend human reason. The Christian faith, properly understood, is a rational reception and acceptance of certain divine revelations. The revelations in question do not include anything that is "above reason". ${ }^{13}$ What God has revealed, in

11 Cf. ibidem.

12 See footnotes $4-8$ above for references.

13 For the view that by dismissing the category of "above reason" Toland rejects Locke's conception of faith, as expressed in the Essay Concerning Human Understanding (hereafter Essay), and adopts Spinoza's position as expressed in the Theological- 
Scripture, is true, clear, and comprehensible, known in all aspects that are relevant to us (CNM, II.II.16). This knowledge is given to us via our ordinary cognitive faculties and is consistent with "our common Notions" (CNM, II.I.5).

Relying on his reading of Locke's Essay, Toland defines reason as "That Faculty of the Soul which discovers the Certainty of any thing dubious or obscure, by comparing it with something evidently known" (CNM, I.II.8). The function of reason is not to provide immediate comprehension and knowledge. Reasoning is needed "when the Mind cannot immediately Perceive the Agreement or Disagreement of any Ideas" (Ibidem.). When the mind can immediately perceive "the Agreement or Disagreement of two or more Ideas", it has knowledge by way of intuition (CNM, I.II.7-8). ${ }^{14}$

It seems to follow that the understanding of divine revelations may take at least some time and effort. Yet, the content of these revelations is ultimately intelligible and conceivable; nothing intrinsically obscure or incomprehensible is included in it. Reasoning is concerned with, and confined to, things of which we have "notions or ideas" (CNM, I.II.9). The rational Christian faith, accordingly, is concerned with things of which (clear and distinct) ideas can be formed.

Divine revelation is a way of informing us about certain matters of fact that were previously unknown to us. Revelation gives knowledge, or evidence, that is the sole ground of faith (CNM, II.II.11). The knowledge of the things that God has revealed is natural, not supernatural, according to Toland. There is no essential difference between our knowledge of natural things such as water or air and the knowledge of divine things acquired via revelation. In both cases, we can have clear and distinct ideas of, and thus conceive and comprehend, the things in question. This is not to say, however, that the ideational grasp of natural and divine objects, or matters of fact, extends to every detail, for "we are accounted to comprehend any thing when its chief Properties and their several Uses are known to us" (CNM, III.II.10). The fact that we do not know how many particles are in a drop of water does not make water mysterious or incomprehensible (Ibidem). Similarly, Toland argues, with the help of Lockean vocabulary, "no Christian Doctrine, no more than any ordinary Piece of Nature, can be reputed a Mystery, because we have not an adequate or compleat Idea of whatever belongs to it" (CNM, III.II.12). ${ }^{15}$ Even if the "real

\footnotetext{
Political Treatise, see I. Leask, "The Undivulged Event in Toland's Christianity Not Mysterious".

14 Thus, for Toland, to know is to perceive certain relations between ideas.

Cf. Locke's Essay, IV.I,II,XVII.

15 Cf. Locke's Essay, II.XXXI.
} 
Essence", or "intrinsick Constitution" of the thing is unknown to us that does not allow us to deem it a mystery (CNM, III.II.16-18). ${ }^{16}$

Toland is well aware of the uses of the term "mystery" in the New Testament and its applications to certain Christian doctrines. But he interprets these uses in compliance with his rationalist agenda: "Mystery in the whole New Testament is never put for anything inconceivable in it self, or not to be judg'd of by our ordinary Notions and Faculties, however clearly reveal'd" (CNM, III.III.35). On the contrary, the word always signifies "some things naturally intelligible enough; but either so vail'd by figurative Words and Rites, or so lodg'd in God's sole Knowledg and Decree, that they could not be discover'd without special Revelation" (Ibidem.).

He specifically discusses the doctrine of bodily resurrection, as stated in 1 Corinthians 15, to show that the articles of Christian faith are intrinsically intelligible:

It is not the Doctrine of the Resurrection then, you see, that is here call'd a Mystery, but only this particular Circumstance of it, viz. that the Living shall at the Sound of the last Trumpet put off their Flesh and Blood, or their Mortality, without Dying, and be in an Instant render'd incorruptible and immortal, as well as those that shall revive. (CNM, III.III.31; cf. III.III.24)

Thus, the content of this revealed doctrine is known and understood. What is unknown at present are the details of the future event described in Scripture. Toland does not explain what consequences might this approach have for other so-called Christian mysteries such as the Trinity or Incarnation.

One condition for the Christian faith to be rational is that the terms and propositions ${ }^{17}$ expressing its doctrines need to be meaningful. While Toland generally relies on Locke's position that linguistic meanings are constituted by ideas in our minds,$^{18}$ he makes no attempt to explain in detail how the words expressing God's revelations gain their meaning and how ideas can represent the revealed divine things. Another condition for faith to be rational is that the assent one gives to propositions expressing the relevant doctrines must be based on knowledge and evidence, not authority:

And seeing the Case stands really thus, all Faith or Perswasion must necessarily consist of two Parts, Knowledg and Assent. 'Tis the last indeed

16 Cf. Locke's Essay, III.III.15-19; III.VI.2.

17 In the 17th century texts studied here, "propositions" mean declarative sentences.

18 To be precise, this position concerns categorematic terms. See Essay, III, esp. III. II-III and III.VII. 
that constitutes the formal Act of Faith, but not without the Evidence of the first: And this is the true Account we have of it all over the New Testament. (CNM, III.IV.54; cf. II.II.11)

In other words, to believe is to know and also approve what one knows. The Christian faith consists in the knowledge of certain revealed matters of fact along with a formal approval of this knowledge. The knowledge in question is given by God, but it does not differ in kind from the knowledge we have of the things of this world. Supernatural reduces to natural, faith merges into knowledge. "Faith is Knowledg", declares Toland himself (CNM, III.IV.66). What I want to point out in this paper is that, according to Toland's view in CNM, the genuine Christian faith is knowledge in a specific sense, namely, it is a special kind of natural knowledge. It is special in its origin, namely, divine revelation, but the origin does not make it essentially different from the knowledge we have of the natural world. Faith as knowledge concerning divine revelations does not require the existence and use of extraordinary cognitive faculties. Neither does it require the existence of supernatural objects.

\section{Browne on Toland, Analogy, and Faith}

In his thorough, critical response to Toland's book, Browne aims to defend the position that the Christian religion does include a number of doctrines that are "above reason" and cannot be fully understood at present. He argues that Toland relies on "two false suppositions", one pertaining to logic and the other to theology. The suppositions are as follows: first, "That Evidence is the only ground of Perswasion", and second, "That now under the Gospel the Vail is perfectly remov'd". ${ }^{19}$ The first supposition will be discussed at the end of this section.

The second, theological supposition is flawed, according to Browne, because the revelation in Scripture is not complete. While he grants that no truths are intrinsically incomprehensible, he holds that some of the revealed divine truths contain more than we are currently able to know and understand. These truths are perfectly known to God, but only partly made known to us, "because they are not suited to our present capacities". ${ }^{20}$

The same view is expressed by Browne's explanation of the biblical sense of "mystery":

19 Answer, pp. 4-5.

20 Ibidem, p. 27. 
a Christian Mystery is something which relates to another life, which it was impossible for us to know, without Divine Revelation; and now that it is reveal'd we know it but in part, and cannot fully comprehend it. Or shorter. It is a Divine Truth reveal'd to us in part. ${ }^{21}$

A Christian mystery, then, is neither fully understood nor completely beyond reason. Instead, each mystery includes two parts or aspects one of which is clear to our reason and the other transcends it. In Browne's own words, each mystery contains " 1 . Something that we do comprehend fully, and 2dly, Something that we have no notion at all of". ${ }^{22}$ While Toland focuses on the first aspect, claiming that the content of divine revelation is entirely penetrable, he is blind to the second aspect of every mystery, namely, the "divine thing" itself whose "real nature" remains hidden from us even after revelation. According to Browne, we do have "clear and distinct ideas" of worldly things that indirectly represent those divine things, but we have no ideas or notions of the divine things "as they are in themselves". Only faith can reach the latter. ${ }^{23}$

Browne disagrees with Toland's view that the divine things revealed in Scripture are known to us just as well as natural things: "This is the point in difference between us, Whether we have as perfect and comprehensible a knowledg of every thing reveal'd in the Gospel, as we have of any thing in Nature. This is what he affirms, and we deny". ${ }^{24}$ Compared to the natural things and their internal constitutions, the Christian mysteries "are infinitely more excellent in themselves; and [...] there is much more behind to be known in them", so "they wou'd deserve the name of Misteries in a much more proper sence than any thing in nature" ${ }^{25}$ There is a further and even bigger difference between these two kinds of things. While natural objects can be perceived and grasped by means of our natural faculties, the objects of another world "exceed our present Capacities of Knowledg", and hence, are said to be "above our Reason". ${ }^{26}$ Browne thinks that the heavenly objects, "as they are in themselves", cannot be perceived or conceived until we have either "new faculties" or the present ones "greatly enlarg'd" ${ }^{27}$ This improvement in cognition will take place in the next life..$^{28}$

However, how can the supernatural objects that we have no idea of be nonetheless represented to us at present, given the cognitive faculties

${ }^{21}$ Ibidem, pp. 13-14.

22 Ibidem, pp. 56-57.

23 Ibidem, pp. 56-60.

24 Ibidem, pp. 113-114.

25 Ibidem, p. 116.

26 Ibidem, pp. 117-119.

27 Ibidem, pp. 123-124.

28 See ibidem, p. 104. 
we have? Browne offers a version of the theory of divine analogy to explain this. He holds that God himself uses analogy as a means of revelation. If God wants to reveal us something, we need to be able to receive his revelations. If the content of these revelations is beyond the grasp of our cognitive capacities and we will not have new ones in this life, there must be some other way for God to disclose his secrets:

Now what I say is this, that we have no proper Idea's of the things of another World, but frame to our selves conceptions of them, from those things in this World whereof we have clear and distinct Idea's. And to make this appear, let us consider that there are but two ways of Gods revealing any thing to us; either by giving us new faculties, or by adapting his Revelations to those we have, which are our Sences and our Reason. He grants that it is not by giving us any new faculties; and therefore since this is done by adapting himself to those faculties we already have, then 'tis plain that he must make use of such words and notions as fall within their proper sphere. ${ }^{29}$

Thus, in his revelations, in Scripture, God has used familiar words and notions, pointing to natural things and relations, and by this means revealed truths about certain divine things that correspond to the natural ones. Our conceptions of the divine things are formed out of the ideas of natural things. In other words, the transcendent objects are revealed and represented to us by means of analogy with natural objects. Currently we do not know what these representations represent. Our faculties are too limited and conceptions too vague and distant to grasp the heavenly realities. The fact that there is indeed such an analogy between the known natural objects and unknown divine objects can be concluded from God's wisdom. ${ }^{30}$

Browne applies the theory of analogy to a number of Christian mysteries such as the Trinity, ${ }^{31}$ the Divinity of Christ $^{32}$ and also bodily resurrection. ${ }^{33}$ I shall focus on the latter to see where exactly Browne's account differs from Toland's. The mystery of bodily resurrection is expressed by the proposition "Our Bodies sown in Corruption, shall be rais'd in Incorruption". ${ }^{34}$ Browne explains how, and to what extent, we can understand this proposition: "[...] we have Idea's in our heads of what $a$ body is; what it is to be sown or laid in the ground; what it is to be rais'd; and what

\footnotetext{
29 Ibidem, p. 39.

30 Ibidem, p. 38.

31 Ibidem, pp. 70-76.

32 Ibidem, pp. 77-83.

33 Ibidem, pp. 103-104.

34 Ibidem, p. 102.
} 
it is for a body to be improv'd when it is so". ${ }^{35}$ While we can conceive this mysterious event by means of ideas that are available to us, the nature of the mystery remains hidden until the event actually takes place. In order to reveal the truth about the supernatural thing, God has chosen words describing certain natural things. Presumably, there is an analogy between the worldly and divine things in question, but currently we can only believe in the resurrection without knowing at all what it will be like. Toland, by contrast, claims that all relevant aspects of bodily resurrection are already known.

Browne takes it that the Christian mysteries are revealed through certain propositions in Scripture and Christian faith involves assent to these propositions. Although the relevant terms and propositions ultimately express supernatural things, their linguistic meanings are constituted by ideas of worldly things. Thus, despite the cryptic divine analogy, the primary meanings of words expressing the Christian mysteries are ideational in character. ${ }^{36}$

As for Toland's supposition "That Evidence is the only ground of Perswasion", Browne rejects it in general and also in the theological context. Evidence is one, but not the only ground of persuasion. Authority can also be a ground of persuasion both in natural and supernatural matters. If a person knows how to prove that "The three angles of a Triangle are equal to two right ones", his persuasion is based on evidence. When I learn from him this truth, I may believe it without being able to prove it. My persuasion is at least partly based on his authority. ${ }^{37}$ In case of revealed propositions, three things need to be considered: " 1 . The meaning of the words. 2. The relation itself, or the very act of revelation. 3. The substance of the thing intended by the Revelation".$^{38}$ Take, for example, the proposition "When Christ appears we shall be like him". ${ }^{39}$ According to Browne, we may assent to this proposition because we (1) know the meaning of these words and also (2) have evidence of its coming from God. However, (3) the substance, or supernatural content, of the proposition is beyond our comprehension. Our belief ${ }^{40}$ concerning the substance of this proposition is based on the authority of the revealer. ${ }^{41}$

On the whole, it could be said that Browne takes the Christian faith to be a set of voluntary beliefs concerning supernatural things that are partly revealed. The supernatural things in question cannot be perceived or con-

35 Ibidem, p. 103; cf. p. 61.

36 See ibidem, p. 39.

37 See ibidem, pp. 21-23, 28.

38 Ibidem, p. 24.

39 Ibidem, pp. 24-25.

40 For Browne, religious belief involves genuine assent and hence is voluntary.

41 See ibidem, pp. 22-29. 
ceived by means of our current cognitive faculties. However, these mysterious things will be perceived in another life where we shall have suitable cognitive capacities. Browne opposes Toland's intention of showing "that there is no such thing as Faith distinct from Knowledg". ${ }^{42}$ He thinks that Toland's account of faith "makes Revelation useless". ${ }^{43}$

\section{Conclusions}

A number of conclusions can be drawn from the comparison of the models of Christian faith proposed by Toland and Browne. To point out main similarities and disparities between these two models, I focus on four facets of the complex relationship between human minds and divine things: revelation, knowledge, representation and belief.

Firstly, both thinkers hold that the Christian revelation is not complete: at least some aspects of the heavenly things are still hidden from us and we will experience them in the afterlife. The difference between Browne's and Toland's views on this point is not so substantial as Browne claims to have shown. Their disagreement on whether or not Christianity involves "mysteries" is, to a large extent, verbal. At the same time, Toland states that all genuine Christian doctrines are entirely comprehensible. Browne realised that some important Christian doctrines, such as the Trinity, may not meet this criterion.

Secondly, it could be said that Toland is epistemically optimistic: he thinks that the unknown aspects of heavenly things are either not fundamentally different from what we already know or do not concern us at all. Browne, by contrast, is epistemically pessimistic: in his view, we lack any knowledge of the heavenly things as they are in themselves. ${ }^{44}$

Thirdly, while Toland does not offer a theory to explain how exactly our ideas represent the heavenly things, Browne's theory of divine analogy leaves us with a mere belief that something unknown in the other world does correspond to our ideas. On Browne's account, the ultimate objects of Christian faith become very distant and mysterious indeed.

Fourthly, Browne rightly observes that, in Toland's hands, faith becomes, in a sense, redundant. As I argued in this paper, Toland takes the Christian faith to be a special kind of natural knowledge. He asserts that the Christian faith has no supernatural objects and does not involve any unclarity or uncertainty. His model of faith leaves no room for a belief into something that one cannot understand or has no idea of. In Browne's

42 Ibidem, p. 173.

43 Ibidem, p. 175.

44 Furthermore, his epistemic pessimism extends not only to the truths of revealed religion, but also to those of natural religion (Ibidem, pp. 39-47, 62). 
view, by contrast, the Christian faith comprises a number of voluntary beliefs concerning supernatural things that are partly revealed but nonetheless remain mysterious to us at present. He holds that, relying on the authority of the revealer, one may assent to propositions describing the supernatural things of which one has no idea at all. It could be said that, in Browne's model, the Christian does not really know what he or she believes in. ${ }^{45}$

\section{Bibliography}

Bishop, J. “Faith". In Stanford Encyclopedia of Philosophy, 2016. https://plato. stanford.edu/entries/faith/

Browne, P. A letter in answer to a book entitled Christianity not mysterious. Dublin: John North, 1697.

Browne, P. The procedure, limits, and extent of human understanding. 2nd ed. London: William Innys, 1729.

Browne, P. Things divine and supernatural conceived by analogy with things natural and human. London: William Innys and Richard Manby, 1733.

Byrne, P. Natural Religion and the Nature of Religion: The Legacy of Deism. London and New York: Routledge, 1989.

Champion J. Republican Learning: John Toland and the Crisis of Christian Culture, 1696-1722. Manchester and New York: Manchester University Press, 2003.

Curtain, T. "Divine Analogy in Eighteenth-Century Irish Philosophy". Journal of Theological Studies, NS, Vol. 65, Pt. 2, 2014: 600-624.

Daniel, S. H. John Toland: His methods, manners, and mind. Montreal: McGill-Queen's University Press, 1984.

Duddy, T. A History of Irish Thought. London and New York: Routledge, 2002.

Fouke, D. C. Philosophy and Theology In A Burlesque Mode: John Toland and "The Way Of Paradox". Amherst, New York: Humanity Books, 2007.

Hefelbower, S. G. The Relation of John Locke to English Deism. University of Chicago Press, 1918.

Hudson, W. The English Deists. London. Pickering \& Chatto, 2009.

Hudson, W., D. Lucci and J. R. Wigelsworth (eds.). Atheism and Deism Revalued. Heterodox Religious Identities in Britain, 1650-1800. Farnham and Burlington: Ashgate, 2014.

Israel, J. I. Radical Enlightenment: Philosophy and the Making of Modernity 16501750. Oxford: Oxford University Press, 2001.

45 This publication was supported by an institutional research grant IUT20-5 from the Estonian Ministry of Education and Research and by the European Union through the European Regional Development Fund (Centre of Excellence in Estonian Studies). 
Jaffro, L. "John Toland and the Moral Teaching of the Gospel". In Philosophy and Religion in Enlightenment Britain. New Case Studies, edited by R. Savage, Oxford, Oxford University Press, 2012, pp. 77-89.

Leask, I. "Personation and Immanent Undermining: On Toland's Appearing Lockean". British Journal for the History of Philosophy 18(2) 2010: 231-256.

Leask, I. "The Undivulged Event in Toland's Christianity Not Mysterious". In Hudson, W., D. Lucci and J. R. Wigelsworth (eds.), 2014, pp. 63-38.

Lechler, G. V. Geschichte des englischen Deismus. Stuttgart und Tübingen: J. G. Cotta, 1841.

Linford, D. "Early-Modern Irreligion and Theological Analogy: A Response to Gavin Hyman's A Short History of Atheism". Secularism and Nonreligion, 5: 3, 2016, pp. 1-8.

Locke, J. An Essay Concerning Human Understanding. Edited by P. H. Nidditch, Oxford: Clarendon Press, 1975 [1690] .

Lucci, D. Scripture and Deism. The Biblical Criticism of the Eighteenth-Century British Deists. Bern: Peter Lang, 2008.

Marko, J. S. Measuring the Distance between Locke and Toland: Reason, Revelation, and Rejection during the Locke-Stillingfleet Debate. Eugene, OR: Pickwick, 2017.

O'Higgins, J. "Browne and King, Collins and Berkeley: Agnosticism or Anthropomorphism?" Journal of Theological Studies, NS, Vol. 27, Pt. 1, 1976: 88-112.

Olscamp, P. J. The Moral Philosophy of George Berkeley. The Hague: Martinus Nijhoff, 1970.

Simonutti, L. "Deism, Biblical Hermeneutics and Philology". In Hudson, W., D. Lucci and J. R. Wigelsworth (eds.) 2014, pp. 45-62.

Stephen, L. History of English Thought in the Eighteenth Century, Vol. 1. London: Smith, Elder, \& Co, 1876.

Sullivan, R. E. John Toland and the Deist controversy: A study in adaptations. Cambridge, Massachusetts and London: Harvard University Press, 1982.

Toland, J. Christianity not mysterious: Or, a treatise shewing, that there is nothing in the gospel contrary to reason, nor above it: and that no Christian doctrine can be properly call'd a mystery. 2nd ed. London: Sam. Buckley, 1696.

Wigelsworth, J. R. Deism in Enlightenment England. Theology, Politics, and Newtonian Public Science. Manchester University Press, 2009.

Winnett, A. R. Peter Browne: Provost, Bishop, Metaphysician. London: SPCK, 1974.

\section{Summary}

\section{Conflicting Models of Faith: Browne vs Toland}

In this paper, I consider two Early Modern conceptions of Christian faith, one proposed by John Toland (1670-1722) and the other by Peter Browne 
(1665-1735). I regard and analyse these conceptions as conflicting models of faith. On the basis of the comparative analysis, I claim that, according to Toland's model, the Christian faith is a special kind of natural knowledge, while, according to Browne's model, it is a set of voluntary beliefs concerning supernatural things that are partly revealed.

\section{Keywords}

John Toland, Peter Browne, deism, faith, knowledge, belief 